\title{
International evidence on ethical mutual fund performance and investment style
}

Citation for published version (APA):

Bauer, R. M. M. J., Koedijk, C. G., \& Otten, R. R. A. E. (2004). International evidence on ethical mutual fund performance and investment style. UM Universiteit Maastricht. LIFE Working Paper

Document status and date:

Published: 01/01/2004

Document Version:

Publisher's PDF, also known as Version of record

\section{Please check the document version of this publication:}

- A submitted manuscript is the version of the article upon submission and before peer-review. There can be important differences between the submitted version and the official published version of record.

People interested in the research are advised to contact the author for the final version of the publication, or visit the DOI to the publisher's website.

- The final author version and the galley proof are versions of the publication after peer review.

- The final published version features the final layout of the paper including the volume, issue and page numbers.

Link to publication

\footnotetext{
General rights rights.

- You may freely distribute the URL identifying the publication in the public portal. please follow below link for the End User Agreement:

www.umlib.nl/taverne-license

Take down policy

If you believe that this document breaches copyright please contact us at:

repository@maastrichtuniversity.nl

providing details and we will investigate your claim.
}

Copyright and moral rights for the publications made accessible in the public portal are retained by the authors and/or other copyright owners and it is a condition of accessing publications that users recognise and abide by the legal requirements associated with these

- Users may download and print one copy of any publication from the public portal for the purpose of private study or research.

- You may not further distribute the material or use it for any profit-making activity or commercial gain

If the publication is distributed under the terms of Article $25 \mathrm{fa}$ of the Dutch Copyright Act, indicated by the "Taverne" license above, 


\title{
International evidence on ethical mutual fund performance and investment style
}

\author{
Rob Bauer ${ }^{\text {a,c }}$, Kees Koedijk ${ }^{\text {b,* }}$, Rogér Otten ${ }^{c}$ \\ ${ }^{a}$ ABP Investments, Schiphol, The Netherlands \\ ${ }^{\mathrm{b}}$ Faculteit Bedrijfskunde, Erasmus University Rotterdam and CEPR, P.O. Box 1738, \\ 3000 DR Rotterdam, The Netherlands \\ ${ }^{\mathrm{c}}$ Maastricht University, Maastricht, The Netherlands \\ Received 23 September 2003; accepted 28 June 2004 \\ Available online 23 September 2004
}

\begin{abstract}
Using an international database containing 103 German, UK and US ethical mutual funds we review and extend previous research on ethical mutual fund performance. By applying a Carhart multi-factor model [Carhart, Journal of Finance 57 (1997) 57] we overcome the benchmark problem most prior ethical studies suffered from. After controlling for investment style, we find no evidence of significant differences in risk-adjusted returns between ethical and conventional funds for the 1990-2001 period. Our results also suggest that ethical mutual funds underwent a catching up phase, before delivering financial returns similar to those of conventional mutual funds. Finally, our performance estimates are robust to the inclusion of ethical indexes, which, surprisingly, are not incrementally capable of explaining ethical mutual fund return variation.
\end{abstract}

(c) 2004 Elsevier B.V. All rights reserved.

JEL classification: G12; G20; G23

Keywords: Mutual funds; Performance evaluation; Style analysis; Ethical investments

\footnotetext{
${ }^{*}$ Corresponding author. Tel.: +31 10408 2790; fax: +31 104089017.

E-mail address: c.koedijk@fbk.eur.nl (K. Koedijk).
} 


\section{Introduction}

One of the astonishing new developments in the financial community is the rise of social and ethical investments during the last decade. ${ }^{1}$ While the origins of ethical investing date back many hundreds of years, the modern roots of social investing can be traced to the political climate of the 1960's. ${ }^{2}$ Issues like the environment, civil rights and nuclear energy served to increase the social awareness of investors. Accordingly, mutual funds were set up with the explicit intention to meet the demand for incorporating ethical criteria in the investment process. This led to a dramatic increase in ethically managed mutual fund assets, an industry which now represents \$153billion in the United States. If we would also include all US private and institutional ethically screened portfolios this number tops the \$2trillion mark at the end of $2000 .^{3}$ At the moment almost $12 \%$ of money under professional management in the United States is part of a socially responsible portfolio.

Because of the sheer size and importance of this movement, the academic community has displayed considerable interest in the financial consequences of investing ethically. The theoretical debate pertaining to the potential virtues of socially responsible investing can be structured along several lines. Hamilton et al. (1993) mention three alternative hypotheses. The first is that socially responsible investing does not add or destroy value in terms of risk-adjusted returns, because corporate social responsibility is not priced. ${ }^{4}$ Their second hypothesis is that socially responsible portfolios deliver lower expected returns compared to regular portfolios, because socially responsible investors are able to influence the value of socially responsible companies upwards by driving down their expected returns and cost of capital. Finally, the third hypothesis posits that the expected returns on stocks of socially responsible firms are higher than the returns on conventional stocks. As also suggested by Moskowitz (1972), this could occur when markets do not price social responsibility correctly. ${ }^{5}$ Hamilton et al., for example, mention the possibility that investors underestimate the likelihood that negative information will be released about companies that are typically considered controversial from an ethical perspective.

\footnotetext{
${ }^{1}$ The term Ethical Investing will be used throughout this paper, instead of the US equivalent, Socially Responsible Investing (SRI).

${ }^{2}$ Ethical investing has ancient origins. In biblical times, Jews made laws with directives on how to invest according to ethical values. In the US, George Fox founded the Quakers in the 16th century. This was a group of investors that applied social criteria to investing, based on their beliefs in human equality and non-violence. They were considered to be the first group of ethical investors.

${ }^{3}$ Figures by Social Invest Forum (2001 Trends Report).

${ }^{4}$ For this reason many financial scholars predominantly adopt a critical stance towards ethical investing, arguing that ethical investing is likely to under-perform over the long term because ethical portfolios are by nature subsets of the market portfolio. Kurtz (1998) labels this perspective 'the Markowitz view'.

5 This is also what management theorists typically assert. Kurtz (1998) refers to the 'Moskowitz view'.
} 
The existing empirical evidence on US data suggests that ethical screening leads to similar or slightly weaker performance relative to comparable unrestricted portfolios. Among others, Diltz (1995); Guerard (1997) and Sauer (1997) concluded that there were no statistically significant differences between the returns of ethically screened and unscreened universes.

Evidence from mutual fund literature is predominantly focused on the US and UK retail markets. Hamilton et al. (1993) and Statman (2000) compared the returns of ethical and regular US funds to each other, and to both the S\&P 500 and the Domini Social Index (DSI). Their Jensen's alpha estimates suggest that the risk-adjusted returns of ethical mutual funds are not different from those of conventional funds. Goldreyer et al. (1999) used an extended sample of ethical funds including equity, bond and balanced funds. Using Jensen's alpha, Sharpe and Treynor ratios, they found that social screening does not affect the investment performance of ethical mutual funds in any systematic way.

As for the UK market, four influential papers appeared during the last decade. The early studies compared ethical funds to market-wide indices like the FT allshare index. Using this methodology Luther et al. (1992) investigated the returns of 15 ethical unit trusts. Their results provided some weak evidence that ethical funds tend to out-perform general market indices. In addition, a bias towards smaller companies for ethical funds was documented. Luther and Matatko (1994) confirmed this small cap bias and demonstrated that comparing ethical funds to a small cap benchmark, improved their relative performance substantially. Subsequently Mallin et al. (1995) attempted to overcome this benchmark problem by conducting a matched pairs test. After matching by fund size and formation date, they reported Jensen's alphas suggesting that ethical mutual funds outperformed their conventional counterparts. Finally, Gregory et al. (1997) argued that using fund size as a matching criterion does not control for a small cap bias in ethical portfolios. Based on a 2-factor Jensen's alpha approach (including a small cap benchmark) they confirmed prior notions of a small cap bias. Secondly, no significant difference between the financial performance of ethical and conventional unit trusts was found.

In addition to this small cap bias, a set of US papers has appeared, attributing the recent out-performance of the DSI index to sector and style biases. For instance, DiBartolomeo (1996); Guerard (1997) and Kurtz (1997) reported that the largecap and growth stock exposures of the DSI were the primary determinants of outperformance, and not a so-called social factor.

The purpose of our paper is to review and extend previous research on ethical mutual funds. We investigate the investment styles of ethical funds, and control for their biasing influences in performance assessment routines. In order to do so we employ more elaborate multi-factor models that control for size, book to market, and momentum effects. More specifically, we build upon the work of Carhart (1997) on performance evaluation, which represents the current standard methodology on mutual fund performance.

Using an international sample of 103 US, UK and German ethical mutual funds we address the central question whether ethical mutual funds differ in terms of 
risk-adjusted return and investment style from a matched sample of conventional mutual funds. Our principal objective will be to investigate whether the return on ethical investments transcends market cycles and style preferences. ${ }^{6}$

The remainder of the paper is organized as follows. Section 2 provides information on our data. Section 3 reports the main empirical results. In Section 4 we evaluate performance and investment style through time. Section 5 explores the added value of ethical benchmark indices when evaluating ethical mutual fund performance. Finally, in Section 6 we present concluding comments.

\section{Data}

\subsection{General market overview}

Table 1 summarizes information on the size of the ethical mutual fund market in several countries. While the US market for ethical mutual funds rose from $\$ 12$ billion in 1995 to $\$ 153$ billion at the end of 2000, the European market for ethical funds is still in an early stage of development. For instance in Belgium, France and Germany ethical funds do not even account for $1 \%$ of the total domestic market for mutual funds. Frontrunners in Europe are Sweden, The Netherlands and the United Kingdom. But even their relative importance is only half that of ethical funds in the US. Overall it can be said that the entire ethical mutual fund market still presents only a marginal part of the traditional market.

\subsection{Ethical mutual funds}

To study the international performance and style of ethical mutual funds we construct a database containing the two most developed retail markets for ethical investors, the United States and the United Kingdom. In addition, our study includes the German mutual fund industry, which is a relatively young but rapidly growing market. By considering these three retail markets we aim to provide robust and consistent outcomes with regard to mutual fund performance and investment style. We restrict our sample to pure, domestic equity funds with at least 12 months of data, excluding balanced and guaranteed funds.

Using Morningstar (US), EIRIS (UK) and Ecoreporter (Germany) we constructed portfolios of mutual funds investing their assets by means of ethical screens. As a reference group, we selected all other equity mutual funds in a certain country that did not explicitly claim to use ethical criteria. Furthermore we divided

\footnotetext{
${ }^{6}$ As we are not interested in individual ethical fund performance we will concentrate on the ethical market as a whole, by grouping funds into portfolios. Although we acknowledge that ethical funds employ a wide variety of ethical screens (for instance exclusion versus best-in-class) we think grouping funds enables us to address the question whether the ethical industry is efficient enough as a whole.
} 
Table 1

Overview of ethical mutual fund market as of 30/12/2000

\begin{tabular}{lccl}
\hline Country & $\begin{array}{l}\text { \# of ethical } \\
\text { mutual funds }\end{array}$ & $\begin{array}{l}\text { Ethical assets under } \\
\text { management in million USD }\end{array}$ & $\begin{array}{l}\text { As a \% of total } \\
\text { mutual fund assets }\end{array}$ \\
\hline Belgium $^{\mathrm{a}}$ & 26 & 602 & $0.80 \%$ \\
France $^{\mathrm{a}}$ & 14 & 371 & $0.01 \%$ \\
Germany $^{\text {Italy }}$ & 22 & 1,317 & $0.04 \%$ \\
Sweden $^{\mathrm{a}}$ & 5 & 2,077 & $0.45 \%$ \\
Switzerland $^{\mathrm{a}}$ & 42 & 1,190 & $1.46 \%$ \\
The Netherlands & 22 & 1,011 & $1.12 \%$ \\
United Kingdom & 11 & 1,309 & $1.20 \%$ \\
United States & 55 & 6,390 & $1.35 \%$ \\
\hline
\end{tabular}

Notes: This table presents the characteristics of the major European ethical mutual fund markets and the United States. The first column presents the total number of ethical mutual funds within a country. The second column provides the amount of total ethical mutual fund assets under management (in USD). The last column presents the $\%$ of the total domestic fund market that is possessed by ethical funds. Sources: Avenzi, VBDO, EIRIS, Socialinvest, Arèse, IMUG.

a Size at $31 / 12 / 99$.

funds into investment categories based on regional focus (domestic versus international), to enhance comparability. Return data were subsequently collected from the CRSP Survivor-bias Free US Mutual Fund Database (United States) and from Datastream (Germany and the United Kingdom). All returns are inclusive of any distributions, net of annual management fees and denoted in local currency. The resultant sample is composed of 103 ethical open-ended equity mutual funds and 4384 conventional mutual funds, with monthly returns from January 1990 through March 2001.

As pointed out by Brown et al. (1992), disregarding dead funds leads to an overestimation of average performance. Our US data are survivorship-bias free. To mitigate a possible survivorship bias for Germany and the UK, we add back funds that were closed at any point in time during the period 1990-1991. Through the national mutual fund publications (Unit Trust Yearbook and Hoppenstedt Fondsführer) we were able to identify dead UK and German funds. Return data for these funds were collected from Datastream. Dead funds were included in the sample until they disappeared. After that, the mutual fund portfolios were reweighted accordingly.

The percentage of mutual funds that disappeared throughout the sample period for Germany, the United Kingdom and the United States is $6 \%, 28 \%$ and $19 \%$, respectively. The influence of excluding non-surviving funds from the analysis becomes evident by comparing the mean returns of survivors and non-survivors with those of surviving funds only. Restricting our sample to surviving mutual funds leads to a substantial overestimation of average returns, namely by $0.14 \%$ (Germany), $0.17 \%$ (United Kingdom) and $0.31 \%$ (United States) per year.

Table 2 provides descriptive information on fund characteristics. Looking at some basic features of ethical mutual funds, we observe that the average ethical fund is 
Table 2

Characteristics of ethical versus conventional funds

\begin{tabular}{|c|c|c|c|c|}
\hline Country & $\begin{array}{l}\text { Fund size } \\
\text { (in mln USD) }\end{array}$ & $\begin{array}{l}\text { Fund expense } \\
\text { ratio }\end{array}$ & $\begin{array}{l}\text { Fund age } \\
\text { (in years) }\end{array}$ & \# of Funds \\
\hline \multicolumn{5}{|l|}{ Germany } \\
\hline \multicolumn{5}{|l|}{ International } \\
\hline Ethical & 73 & 1.40 & 5.0 & 16 \\
\hline Conventional & 323 & 1.04 & 4.8 & 114 \\
\hline \multicolumn{5}{|c|}{ United Kingdom } \\
\hline \multicolumn{5}{|l|}{ Domestic } \\
\hline Ethical & 48 & 1.24 & 6.4 & 20 \\
\hline Conventional & 176 & 1.19 & 9.2 & 300 \\
\hline \multicolumn{5}{|l|}{ International } \\
\hline Ethical & 89 & 1.49 & 7.5 & 12 \\
\hline Conventional & 107 & 1.33 & 8.5 & 96 \\
\hline \multicolumn{5}{|l|}{ United States } \\
\hline \multicolumn{5}{|l|}{ Domestic } \\
\hline Ethical & 154 & 1.49 & 5.4 & 50 \\
\hline Conventional & 610 & 1.32 & 9.5 & 2806 \\
\hline \multicolumn{5}{|l|}{ International } \\
\hline Ethical & 140 & 1.71 & 4.1 & 5 \\
\hline Conventional & 385 & 1.64 & 7.3 & 1068 \\
\hline
\end{tabular}

Notes: Table 2 reports the main characteristics of the funds in our total sample. Within a country we group funds by regional objective. Average fund sizes are in million US dollars as of 31/12/2000. Expense ratios are presented as a percentage of the assets invested and Fund Age is denoted by the number of years the fund is in existence.

typically smaller in size, and has a higher expense ratio. ${ }^{7}$ Furthermore, as indicated by the number of years a fund exists, conventional funds tend to be older and more mature than ethical mutual funds.

To account for the possible return differences between ethical mutual funds and conventional funds, we compare the performance of ethical funds with a matched sample of conventional funds using fund age and size as matching criteria. For each ethical fund we develop a matched sample containing three appropriate conventional

\footnotetext{
${ }^{7}$ Note however that the European expense ratios should be interpreted with care. Recent research by Fitzrovia International, a London-based fund research firm, showed that the reported costs for UK-funds are not the same as the true costs because administration costs, legal and audit fees are not included. The company thinks that the best guess would be to double the reported fees to get the true total expense ratio (TER). Currently they are studying other European countries as well, but the assumption might be that this relation holds for these countries as well. The Investment Company Institute (ICI) in Washington, DC has studied the situation in the Unites States and found that the TERs are declining. Because however the SEC closely monitors US fees, as they appear in a fund's prospectus, the difference between the true TER and the one reported will not be that large for the US market. For a more detailed discussion on European fees see Otten and Schweitzer (2002).
} 
Table 3

Summary statistics on ethical versus matched conventional funds 1990:01-2001:03

\begin{tabular}{|c|c|c|c|c|}
\hline Country & Return & $\begin{array}{l}\text { Standard } \\
\text { deviation }\end{array}$ & $\begin{array}{l}\text { Fund expense } \\
\text { ratio }\end{array}$ & \# of Funds \\
\hline \multicolumn{5}{|l|}{ Germany } \\
\hline \multicolumn{5}{|l|}{ International } \\
\hline Ethical & 4.77 & 14.13 & 1.40 & 16 \\
\hline Conventional & 8.20 & 16.21 & 1.14 & 48 \\
\hline Worldscope World & 10.33 & 17.58 & & \\
\hline \multicolumn{5}{|l|}{ United Kingdom } \\
\hline \multicolumn{5}{|l|}{ Domestic } \\
\hline Ethical & 9.81 & 13.11 & 1.24 & 20 \\
\hline Conventional & 9.27 & 13.68 & 1.08 & 60 \\
\hline Worldscope UK & 10.39 & 14.39 & & \\
\hline \multicolumn{5}{|l|}{ International } \\
\hline Ethical & 8.92 & 15.16 & 1.49 & 12 \\
\hline Conventional & 8.91 & 14.36 & 1.37 & 36 \\
\hline Worldscope World & 6.91 & 16.65 & & \\
\hline \multicolumn{5}{|l|}{ United States } \\
\hline \multicolumn{5}{|l|}{ Domestic } \\
\hline Ethical & 13.09 & 13.32 & 1.49 & 50 \\
\hline Conventional & 13.47 & 14.11 & 1.32 & 150 \\
\hline FF market index & 14.66 & 14.21 & & \\
\hline \multicolumn{5}{|l|}{ International } \\
\hline Ethical & 11.95 & 13.91 & 1.71 & 5 \\
\hline Conventional & 11.23 & 13.97 & 1.64 & 15 \\
\hline Worldscope World & 11.67 & 13.28 & & \\
\hline
\end{tabular}

Notes: Table 3 reports summary statistics on all ethical funds and a matched sample of conventional funds. Matching occurred by fund age and fund size. Within a country we group funds by regional objective. Ethical and conventional fund returns are calculated based on an equally weighted portfolio of all funds. The return data are annualised with reinvestment of all distributions, based on local currencies. All returns are net of expenses. Besides fund returns we also provide summary statistics on relevant market-wide benchmarks for each country and/or region. Expense ratios are presented as a percentage of the assets invested.

funds. Subsequently, we compute the equal-weighted returns of all funds in our matched samples. Table 3 reports summary statistics pertaining to our matched mutual fund portfolios. These simple statistics suggest that mainly German ethical funds under-perform their conventional peers and relevant indices, while in other countries the performance difference between ethical mutual funds and conventional investments is less pronounced.

\subsection{Benchmarks}

In the basic 1-factor Jensen's alpha analysis we make use of market-wide equity indices supplied by Worldscope. In comparison to, for instance, MSCI indices, Worldscope aims at covering $98 \%$ of market capitalisation, while MSCI mainly 
serves as a large cap proxy. ${ }^{8}$ For the domestic US mutual funds, we employ the Fama \& French market index to approximate the market portfolio. Besides these indices, we also consider the explanatory power of several ethical indices that have been launched recently. These include the DSI, the ethical balanced index by Ethical Investment Research Service (EIRIS) and the Dow Jones Sustainability indices (DJSGI).

In constructing our version of the Carhart (1997) 4-factor model, we consider all stocks in the Worldscope universe for each country/region. For the excess market return we take the return of all stocks in the Worldscope universe that are larger than \$25 million, minus the 1-month inter-bank rate. We then rank all stocks based on size and assign the bottom $20 \%$ of total market capitalization to the small portfolio. The remaining part is allocated to the large stock portfolio. SMB is the return difference between small and large. For the HML factor all stocks are ranked on their book-to-market ratio. In line with Fama and French (1992) we then assign the top $30 \%$ of market capitalization to the high book-to-market portfolio and the bottom $30 \%$ to the low book-to-market portfolio. HML is obtained by taking the return difference between the low book-to-market portfolio and the high book-to-market portfolio. The momentum factor portfolio is formed by ranking all stocks on their prior 12-month return. The return difference between the top 30\% and bottom $30 \%$ by market capitalization then provides us with the momentum factor returns. ${ }^{9}$ This procedure is repeated every month in order to obtain a rolling momentum factor. All factor portfolios are value-weighted.

\section{Empirical results}

\subsection{CAPM model}

The main model used in studies on ethical mutual fund performance is a CAPMbased single-index model. The intercept of such a model, $\alpha_{i}$, gives the Jensen alpha, which is typically interpreted as a measure of out- or under-performance relative to a market proxy. 10

$$
R_{i t}-R_{f t}=\alpha_{i}+\beta_{i}\left(R_{m t}-R_{f t}\right)+\varepsilon_{i t}
$$

where $R_{i t}$ is the return on fund $i$ in month $t, R_{f t}$ the return on a local one month T-bill in month $t, R_{m t}$ the return on the relevant equity benchmark in month $\mathrm{t}$ and $\varepsilon_{i t}$ an error term.

Table 4 presents the results of applying Eq. (1) on our matched samples. Per country and regional scope, we compute Jensen's alpha for both the portfolio of ethical

\footnotetext{
${ }^{8}$ Alternatively we used the relevant MSCI indices. Based on results not reported in the paper we conclude this does not have an influence on our results.

${ }^{9}$ The construction of these factor portfolios was done using the on-line research tool by Style Research Ltd.

${ }^{10}$ See Jensen (1968).
} 
Table 4

Results CAPM model

\begin{tabular}{lccc}
\hline Country/region & Alpha & Market & $R_{\text {adj }}^{2}$ \\
\hline Germany & & & \\
International & & & 0.79 \\
Ethical & $-4.20^{* *}$ & $0.82^{* * * *}$ & 0.76 \\
Conventional & -1.17 & $-0.08^{* * *}$ & 0.07 \\
Difference & -3.03 & & \\
United Kingdom & & & 0.80 \\
Domestic & & $0.82^{* * *}$ & 0.92 \\
Ethical & -0.22 & $0.94^{* * *}$ & 0.09 \\
Conventional & -1.02 & $-0.12^{* * *}$ & \\
Difference & 0.80 & & 0.68 \\
International & & $0.76^{* * *}$ & 0.90 \\
Ethical & 1.71 & $0.84^{* * *}$ & 0.02 \\
Conventional & 0.32 & $-0.08^{* * *}$ & \\
Difference & 1.39 & & 0.01 \\
United States & & & 0.85 \\
Domestic & & 0.96 & 0.94 \\
Ethical & -0.77 & $0.92^{* * *}$ & 0.01 \\
Conventional & -0.85 & $-0.06^{* * *}$ & \\
Difference & 0.08 & & $0.97^{* * *}$ \\
International & & -0.01 & \\
Ethical & 0.29 & 0.14 & \\
Conventional & & & \\
Difference & & & \\
\hline Notes: & & & \\
\hline
\end{tabular}

Notes: Table 4 reports the results of the estimation of Eq. (1) for the 1990:01-2001:03 period. Reported are the OLS estimates for each country and/or region, and within countries for both ethical and matched conventional funds. Difference is a portfolio which is constructed by subtracting matched conventional from ethical fund returns.

$$
R_{i t}-R_{f t}=\alpha_{i}+\beta_{i}\left(R_{m t}-R_{f t}\right)+\varepsilon_{i t}
$$

where $R_{t}$ is the fund return, $R_{f t}$ the risk-free rate and $R_{m t}$ the return on the relevant benchmark of the individual countries. All returns are in local currencies and net of costs. All alphas are annualised.

* Significant at the $10 \%$ level.

** Significant at the $5 \%$ level.

*** Significant at the $1 \%$ level.

funds and the matched portfolio of conventional funds. To enhance comparability we also evaluate a 'difference' portfolio, which is constructed by subtracting conventional fund returns from ethical fund returns. This portfolio serves to examine differences in risk and return between the two investment approaches. Using this approach, we implicitly attribute differences in the risk-adjusted average performance between ethical funds and conventional funds to ethical screens.

From Table 4 two conclusions can be drawn. First, we find no statistically significant difference in performance (alpha) between ethical and conventional mutual funds. In all examined countries, the alpha estimates for the 'difference' portfolios 
are insignificant. Second, as indicated by differences in exposure to market betas, ethical funds tend to be less market sensitive than their conventional counterparts.

If international funds would over- or under-weigh some countries in their portfolio, the use of a general international benchmark might lead to biased results. An example is the home-bias phenomenon, indicating that funds tend to over-weigh domestic stocks at the expense of limited foreign exposure. To test for this phenomenon we ran several alternative specifications of Eq. (1). For instance, we included a local equity index next to the international equity index. As the local and international indices usually are highly correlated we ran 2-step regressions to disentangle the two effects. Next, we also ran a specification in which we replaced the Worldscope international index by an ex-country index (excluding the relevant country) and then add the country index as a separate index. Based on results not reported here, we concluded that the weighting of the international benchmark returns does not influence our results, as the alphas obtained under the three alternative specifications differed only marginally. ${ }^{11}$

\subsection{Multi-factor model}

The need for a multi-factor asset-pricing model stems from the recent literature on the cross-sectional variation of stock returns (see, e.g. Fama and French, 1993, 1996; Chan et al., 1996). The results of these studies lead us to question the adequacy of a single index model to explain mutual fund performance. For this reason, the Fama and French (1993) 3-factor model has been considered to give a better explanation of fund behaviour. Besides containing a value-weighted market proxy, the model includes two additional risk proxies, namely the returns on size- and book-tomarket-sorted equity portfolios. Although this model already mitigates average CAPM pricing errors, it is unable to explain the cross-sectional variation in momentum-sorted portfolio returns. Therefore, Carhart (1997) extends the Fama-French model by adding a fourth factor that captures the Jegadeesh and Titman (1993) momentum anomaly. The resulting model is consistent with a market equilibrium model with four risk factors. Alternatively, it can be interpreted as a performance attribution model, where the coefficients and premia on the factor-mimicking portfolios indicate the proportion of mean return attributable to four widely pursued investment strategies.

Formally, we estimate

$$
R_{i t}-R_{f t}=\alpha_{i}+\beta_{0 i}\left(R_{m t}-R_{f t}\right)+\beta_{1 i} \mathrm{SMB}_{t}+\beta_{2 i} \mathrm{HML}_{t}+\beta_{3 i} \mathrm{Mom}_{t}+\varepsilon_{i t}
$$

where $\mathrm{SMB}_{t}=$ the difference in return between a small cap portfolio and a large cap portfolio at time $t ; \mathrm{HML}_{t}=$ the difference in return at time $t$ between a portfolio containing 'value' stocks (with a high book-to-market ratio) and one consisting of 'growth' stocks (with a low book-to-market ratio); $\mathbf{M o m}_{t}=$ the difference in return

\footnotetext{
${ }^{11}$ These results are available upon request with the authors.
} 
between a portfolio of past 12 months winners and a portfolio of past 12 month losers at time $t$.

Table 5 summarizes the results of estimating the multi-factor model. First, we notice an increase in average $R_{\text {adj }}^{2}$ for the multi-factor models, compared to the 1-factor CAPM models. This confirms our expectation that multifactor models are superior in explaining mutual fund returns. Second, ethical funds tend to have less exposure to the market portfolio in comparison to conventional funds, which corroborates

Table 5

4-Factor Carhart Model

\begin{tabular}{|c|c|c|c|c|c|c|}
\hline Country/region & 4-factor Alpha & Market & SMB & HML & Mom & $R_{\mathrm{adj}}^{2}$ \\
\hline \multicolumn{7}{|l|}{ Germany } \\
\hline \multicolumn{7}{|l|}{ International } \\
\hline Ethical & $-3.81^{* *}$ & $0.73^{* * *}$ & $0.33^{* * *}$ & $-0.03^{*}$ & $0.05^{* *}$ & 0.82 \\
\hline Conventional & -1.40 & $0.79^{* * *}$ & $0.17^{*}$ & -0.00 & $0.13^{* *}$ & 0.79 \\
\hline Difference & -2.41 & $-0.06^{* *}$ & $0.16^{* *}$ & -0.03 & $-0.08^{* *}$ & 0.12 \\
\hline \multicolumn{7}{|l|}{ United Kingdom } \\
\hline \multicolumn{7}{|l|}{ Domestic } \\
\hline Ethical & 0.37 & $0.83^{* * *}$ & $0.47^{* * *}$ & $-0.05^{* * *}$ & $0.04^{* *}$ & 0.93 \\
\hline Conventional & -1.41 & $0.94^{* * *}$ & $0.31^{* * *}$ & $0.30^{* * *}$ & $0.10^{* *}$ & 0.89 \\
\hline Difference & 1.78 & $-0.11^{* * *}$ & $0.16^{* * *}$ & $-0.35^{* * *}$ & 0.06 & 0.27 \\
\hline \multicolumn{7}{|l|}{ International } \\
\hline Ethical & 2.26 & $0.80^{* * *}$ & $0.71^{* * *}$ & $-0.12^{* * *}$ & $0.13^{* * *}$ & 0.80 \\
\hline Conventional & 0.37 & $0.85^{* * *}$ & $0.05^{* * *}$ & $0.06^{* *}$ & -0.02 & 0.91 \\
\hline Difference & 1.89 & $-0.05^{* *}$ & $0.65^{* * *}$ & $-0.18^{* * *}$ & $0.15^{* * *}$ & 0.19 \\
\hline \multicolumn{7}{|l|}{ United States } \\
\hline \multicolumn{7}{|l|}{ Domestic } \\
\hline Ethical & -0.46 & $0.91^{* * *}$ & $0.08^{* * *}$ & 0.01 & $-0.01^{*}$ & 0.96 \\
\hline Conventional & -1.21 & $0.98^{* * *}$ & $0.15^{* * *}$ & $0.10^{* *}$ & 0.00 & 0.95 \\
\hline Difference & 0.75 & $-0.07^{* *}$ & $-0.07^{* *}$ & $-0.09^{*}$ & -0.01 & 0.09 \\
\hline \multicolumn{7}{|l|}{ International } \\
\hline Ethical & -0.97 & $0.92^{* * *}$ & -0.04 & 0.06 & $0.20^{* * *}$ & 0.89 \\
\hline Conventional & -1.12 & $0.93^{* * *}$ & $0.27^{* * *}$ & $0.09^{* *}$ & $0.11^{* * *}$ & 0.91 \\
\hline Difference & 0.15 & -0.01 & $-0.31^{* * *}$ & -0.03 & $0.09^{* *}$ & 0.18 \\
\hline
\end{tabular}

Notes: The table reports the results of the estimation of Eq. (2) for the 1990:01-2001:03. Reported are the OLS estimates for each country and/or region, and within regions for both ethical and matched conventional funds. Difference is a portfolio which is constructed by subtracting matched conventional from ethical fund returns.

$$
R_{t}-R_{f t}=\alpha+\beta_{0}\left(R_{m t}-R_{f t}\right)+\beta_{1} \mathrm{SMB}_{t}+\beta_{2} \mathrm{HML}_{t}+\beta_{3} \mathrm{Mom}_{t}+\varepsilon_{i t}
$$

where $R_{t}$ is the fund return, $R_{f t}$ the risk-free rate, $R_{m}$ the return on the total Worldscope universe, and SMB and HML the factor-mimicking portfolios for size and book-to-market. Mom is a factor-mimicking portfolio for the 12-month return momentum. All alphas in the table are annualised. T-stats are heteroskedasticity consistent.

* Significant at the $10 \%$ level.

** Significant at the 5\% level.

*** Significant at the $1 \%$ level. 
Table 6

Difference in Performance after and before management fees are deducted

\begin{tabular}{lcc}
\hline Country/region & After fees alpha & Before fees alpha \\
\hline Germany & -2.41 & -2.15 \\
International & & \\
United Kingdom & 1.78 & 1.94 \\
Domestic & 1.89 & 2.01 \\
International & & \\
United States & 0.75 & 0.92 \\
Domestic & 0.15 & 0.21 \\
International &
\end{tabular}

This table gives the difference in alpha between ethical and matched conventional mutual funds after fees are deducted (column 2) and before (column 3) fees are deducted from fund returns. All alphas are annualized. After fees alphas are copied from Table 5.

* Significant at the $10 \%$ level.

${ }^{* *}$ Significant at the $5 \%$ level.

**** Significant at the $1 \%$ level.

our previous 1-factor results. Third, German and UK ethical funds are heavily exposed to small caps while US funds, on the other hand, are relatively more invested in large caps. Fourth, all ethical fund portfolios are either more growth-oriented or less value-oriented compared to the matched samples of conventional funds. This is in line with, for instance, Guerard (1997) who finds a growth bias in the DSI index. A reason for the high proportion of growth stocks may lie in the exclusion of traditional value sectors like chemical, energy and basic industries. As these sectors typically have a higher environmental risk, ethical portfolios are often under-weighted with respect to these sectors, which in turn leads to a growth stock orientation. Finally, after controlling for market risk, size, book-to-market and momentum the difference in return between ethical and conventional funds remains statistically insignificant for all three countries. ${ }^{12}$

\subsection{The influence of fees on performance}

As pointed out by the summary statistics reported in Table 2, the average ethical fund is more expensive (expense ratio) than a comparable conventional fund. To investigate the influence of these fund characteristics on the difference between ethical and conventional mutual fund performance, we carry out an additional robustness check. In Table 6 we compare the alpha of the 'difference' portfolio before and after deducting management fees. The alpha before fees is calculated by adding back management fees to the fund returns before running the 4-factor model. The results

\footnotetext{
${ }^{12} \mathrm{We}$ also considered a conditional performance evaluation methodology in spirit similar to Chen and Knez (1996) and Ferson and Schadt (1996). The outcomes do not affect the conclusions in this paper.
} 
in Table 6 confirm our previous observations: the difference in return between ethical and conventional mutual funds is statistically insignificant for all three countries.

\section{Development of relative performance through time}

The next issue we will address in this study is the development of relative performance through time. In order to detect whether the rather young ethical investment industry is undergoing changes we divide our sample period into three non-overlapping sub-samples. Table 7 reports the 4-factor alpha estimates for three different subperiods.

The observed differences in alpha between ethical and conventional funds point to an interesting development: during the period 1990-1993 most of our ethical mutual fund portfolios provided a lower risk-adjusted return compared to their conventional peers. In three cases, this underperformance is statistically significant at the usual cut-off levels. During subsequent periods, however, this negative performance differential weakened and changed sign. Final sub-sample results show that ethical mutual funds provided a superior risk-adjusted return over the period 1998-2001, although the reported alpha is significant in only two cases. One exception is found in the UK market, where domestic ethical mutual fund performance easily holds up with conventional fund performance throughout the entire period.

Table 7

Difference between Ethical and Conventional funds for 3 Sub-periods

\begin{tabular}{llll}
\hline Country/region & $\begin{array}{l}\text { 4-Factor alpha } \\
1990-1993\end{array}$ & $\begin{array}{l}\text { 4-Factor alpha } \\
1994-1997\end{array}$ & $\begin{array}{l}\text { 4-Factor alpha } \\
1998-2001\end{array}$ \\
\hline $\begin{array}{l}\text { Germany } \\
\text { International }\end{array}$ & $-2.86^{*}$ & $-3.47^{*}$ & 0.29 \\
United Kingdom & & & \\
$\begin{array}{l}\text { Domestic } \\
\text { International }\end{array}$ & 1.57 & $3.01^{* *}$ & 0.40 \\
United States & -2.04 & $3.56^{*}$ & $4.82^{*}$ \\
$\begin{array}{l}\text { Domestic } \\
\text { International }\end{array}$ & $-2.17^{*}$ & & $3.61^{* *}$ \\
\hline
\end{tabular}

Notes: Table 7 presents the results of estimating Eq. (2) for three different sub-periods. Reported are the differences between 4-factor alphas for ethical and matched conventional funds.

$$
R_{t}-R_{f t}=\alpha+\beta_{0}\left(R_{m t}-R_{f t}\right)+\beta_{1} \mathrm{SMB}_{t}+\beta_{2} \mathrm{HML}_{t}+\beta_{3} \mathrm{Mom}_{t}+\varepsilon_{i t}
$$

where $R_{t}$ is the fund return, $R_{f t}$ the risk-free rate, $R_{m}$ the return on the total Universe according to Worldscope, and SMB and HML the factor-mimicking portfolios for size and book-to-market. Mom is a factormimicking portfolio for the 12-month return momentum. All alphas in the table are annualised. $T$-stats are heteroskedasticity consistent.

* Significant at the $10 \%$ level.

** Significant at the 5\% level.

*** Significant at the $1 \%$ level. 
Table 8

Ethical indices 1994-2000

\begin{tabular}{|c|c|c|c|c|c|c|c|c|c|c|c|c|}
\hline Country/region & $\begin{array}{l}\text { CAPM } \\
\text { alpha }\end{array}$ & Market & $R_{\mathrm{adj}}^{2}$ & $\begin{array}{l}\text { DJSI } \\
\text { alpha }\end{array}$ & Market & $R_{\mathrm{adj}}^{2}$ & $\begin{array}{l}\text { EIRIS } \\
\text { alpha }\end{array}$ & Market & $R_{\mathrm{adj}}^{2}$ & $\begin{array}{l}\text { DSI } \\
\text { alpha }\end{array}$ & Market & $R_{\mathrm{adj}}^{2}$ \\
\hline Germany & & & & & & & & & & & & \\
\hline $\begin{array}{l}\text { International } \\
\text { Ethical }\end{array}$ & -0.99 & $0.77^{* * *}$ & 0.84 & -3.20 & $0.69^{* * *}$ & 0.67 & & & & & & \\
\hline $\begin{array}{l}\text { United Kingdom } \\
\text { Domestic }^{\#}\end{array}$ & & & & & & & & & & & & \\
\hline Ethical & -1.00 & $0.83^{* * *}$ & 0.80 & & & & -1.12 & $0.82^{* * *}$ & 0.80 & & & \\
\hline $\begin{array}{l}\text { International } \\
\text { Ethical }\end{array}$ & 1.12 & $0.70^{* * *}$ & 0.60 & -1.91 & $0.62^{* * *}$ & 0.50 & & & & & & \\
\hline $\begin{array}{l}\text { United States } \\
\text { Domestic } \\
\text { Ethical }\end{array}$ & -0.92 & $0.92^{* * *}$ & 0.97 & -0.27 & $0.66^{* * *}$ & 0.71 & & & & -1.83 & $0.84^{* * *}$ & 0.85 \\
\hline $\begin{array}{l}\text { International } \\
\text { Ethical }\end{array}$ & 0.73 & $0.99^{* * *}$ & 0.87 & -3.12 & $0.90^{* * *}$ & 0.83 & & & & & & \\
\hline
\end{tabular}

Notes: Table 8 reports the results of using three ethical indices in estimating Eq. (1) for the ethical funds only. The indices used are the Dow Jones Sustainability Indices (DJSI), the EIRIS balanced ethical index and the DSI index. As the DJSI was launched in 1994 we only consider the 1994-2000 period for both the CAPM and ethical benchmarks results.

* Significant at the $10 \%$ level.

${ }^{* * *}$ Significant at the $5 \%$ level.

*** Significant at the $1 \%$ level.

\# 1991:01-1999:05. 
Taken as a whole, the observations from Table 7 suggest that ethical mutual funds underwent a catching-up phase, possibly due to learning, before delivering financial returns similar to those of conventional mutual funds.

\section{Ethical versus conventional benchmark indices}

Finally, we turn to the incremental usefulness of ethical benchmarks in evaluating ethical mutual funds. Given the fact that ethical mutual funds invest subject to ethical constraints, one can argue that their holdings are likely to be different from those of conventional mutual funds. Therefore, a plausible hypothesis is that ethical equity indices are more powerful in explaining ethical mutual fund return variation compared to conventional equity indices. This in turn might affect our alpha estimates. To test this hypothesis, we use several ethical equity indices to measure ethical mutual fund performance. For all international funds we use the Dow Jones Sustainability Global Index (DJSI). Domestic UK funds are evaluated against the Ethical balanced index from EIRIS, and domestic US funds are investigated by using independently the Dow Jones Sustainability US Index and the DSI.

In Table 8 we present the results of considering ethical indices. For reasons of comparison we only examine the 1994-2000 period, since the Dow Jones indices were launched in 1994. Accordingly, the results on the CAPM model with common indices are also based on the 1994-2000 period.

From using ethical indices two clear observations emerge. First, our results do not support the hypothesis that ethical equity indices are incrementally able to explain ethical mutual fund returns. On the contrary, standard indices appear to be more useful in explaining ethical fund returns. In all cases but one, the $R_{\text {adj }}^{2}$ from the model that includes an ethical index is lower than the $R_{\text {adj }}^{2}$ of the standard CAPM model. A second observation is that ethical funds are not able to out-perform their ethical index.

\section{Conclusion}

Although the ethical mutual fund market witnessed an unprecedented growth in assets during the last decade, the industry still only represents an insignificant part of the total retail market. A critical factor that determines the acceptance of ethical mutual funds into the mainstream investment arena is their financial performance. Therefore, using an international database of 103 ethical mutual funds, this paper analyzed ethical mutual fund performance and investment style. While prior work typically employed market-wide indices to evaluate ethical mutual fund performance, this paper explored the added value of more elaborated multi-factor models. Not only does our approach improve performance measurement, it also allows for more detailed mutual fund style analysis. Apart from using a standard CAPM 1-factor model, we also considered the Carhart (1997) 4-factor asset-pricing model that controls for size, book-to-market and stock price momentum. 
Our study reports three interesting results. First, we find no evidence of a statistically significant difference in return between ethical and conventional mutual fund returns after controlling for common factors like size, book-to-market and momentum. Second, ethical mutual funds exhibit distinct investment styles in comparison to conventional funds. For example, ethical funds are typically less exposed to market return variability compared to conventional funds. Additionally, UK and German ethical funds and are heavily exposed to small caps, while ethical funds in the US, on the other hand, invest more in large caps compared to their conventional peers. Furthermore, ethical mutual funds tend to be more growth-oriented, or less valueoriented.

Subsequently, we investigated the returns of ethical mutual funds relative to those of their conventional counterparts through time, using three sub-periods. Our findings provide support for the idea that ethical mutual funds went through a so-called catching-up phase, possibly due to learning. After having under-performed their conventional peers significantly in the beginning of the 1990's, ethical mutual funds provided average risk-adjusted returns matching those of conventional funds over the 1998-2001 period.

Finally, we evaluated fund performance using some well-known ethical indices. Surprisingly, we found that ethical indices perform worse than standard indices in explaining ethical mutual fund returns. Our conclusions with respect to fund performance were, however, unaffected.

\section{Acknowledgements}

We are grateful to the U.S. Social Invest Forum for awarding this paper the 2002 Moskowitz Prize for Outstanding Research in Socially Responsible Investing. Furthermore, we would like to thank Mark Carhart and Eugene Fama for providing data on the US factor portfolios, and Bjorn Kleintjens, Peter Steegmans and Benjamin Steven for collecting parts of our mutual fund dataset. We also thank Ben Hardt and Alexander Barkawi for respectively supplying data on the DSI index and Dow Jones Sustainability indices. The European and International data on factor portfolios were constructed using Style Research Ltd, London. Helpful comments by an anonymous referee, Jeroen Derwall, David Diltz, David Hsieh, Lloyd Kurtz, Roderick Molenaar, Theo Nijman, Robert Schwob, Pieter Jelle van der Sluis, Meir Statman, participants of the Fall 2002 Inquire-Europe meeting in Stockholm, the 2002 TBLI meeting in Brussels and the 2002 AFBC in Sydney, are appreciated. All remaining errors are the sole responsibility of the authors. The views expressed in this paper are not necessarily shared by ABP Investments.

\section{References}

Brown, S.J., Goetzmann, W.N., Ibbotson, R.G., Ross, S.A., 1992. Survivorship bias in performance studies. Review of Financial Studies 5, 553-580. 
Carhart, M., 1997. On persistence in mutual fund performance. Journal of Finance 52, 57-82.

Chan, L.K., Jegadeesh, N., Lakonishok, J., 1996. Momentum strategies. Journal of Finance 51, 16811714.

Chen, Z., Knez, P.J., 1996. Portfolio performance measurement: Theory and applications. Review of Financial Studies 9, 511-556.

DiBartolomeo, D., 1996. Explaining and controlling the returns on socially screened US equity portfolios. Presentation to New York Society of Security Analysts, September 10.

Diltz, J.D., 1995. Does social screening affect portfolio performance? The Journal of Investing 1, 64-69.

Fama, E., French, K.R., 1992. The cross-section of expected stock returns. Journal of Finance 47, 427465.

Fama, E., French, K.R., 1993. Common risk factors in the returns on stocks and bonds. Journal of Financial Economics 33, 3-53.

Fama, E., French, K.R., 1996. Multifactor explanations of asset pricing anomalies. Journal of Finance 51, $55-84$.

Ferson, W., Schadt, R., 1996. Measuring fund strategy and performance in changing economic conditions. Journal of Finance 51, 425-462.

Goldreyer, E.F., Ahmed, P., Diltz, J.D., 1999. The performance of socially responsible mutual funds: Incorporating sociopolitical information in portfolio selection. Managerial Finance 25 (1), 23-36.

Gregory, A., Matatko, J., Luther, R., 1997. Ethical unit trust financial performance: Small company effects and fund size effects. Journal of Business Finance and Accounting 24 (5), 705-724.

Guerard, J.B., 1997. Is there a cost to being socially responsible in investing? The Journal of Investing, 1118.

Hamilton, S., Jo, H., Statman, M., 1993. Doing well while doing good? The investment performance of socially responsible mutual funds. Financial Analysts Journal 49 (6), 62-66.

Jegadeesh, N., Titman, S., 1993. Returns to buying winners and selling losers: Implications for stock market efficiency. Journal of Finance 48, 65-91.

Jensen, M., 1968. The performance of mutual funds in the period 1945-1964. Journal of Finance 23, 389416.

Kurtz, L., 1997. No effect, or no net effects? Studies on socially responsible investing. The Journal of Investing, 37-49.

Kurtz, L., 1998. Mr. Markowitz, Meet Mr. Moskowitz' - A review of studies on socially responsible investing. The Investment Research Guide to Socially Responsible Investing.

Luther, R.G., Matatko, J., Corner, D., 1992. The investment performance of UK ethical unit trusts. Accounting, Auditing and Accountability Journal 5 (4), 57-70.

Luther, R.G., Matatko, J., 1994. The performance of ethical unit trusts: Choosing an appropriate benchmark. British Accounting Review 26, 77-89.

Mallin, C.A., Saadouni, B., Briston, R.J., 1995. The financial performance of ethical investment funds. Journal of Business Finance and Accounting 22 (4), 483-496.

Moskowitz, M., 1972. Choosing socially responsible stocks. Business and Society Review, 71-75.

Otten, R., Schweitzer, M., 2002. A comparison between the European and the U.S. mutual fund industry. Managerial Finance, 14-34.

Sauer, D.A., 1997. The impact of social-responsibility screens on investment performance: Evidence from the Domini 400 social index and domini equity mutual fund. Review of Financial Economics 6 (2), $137-149$.

Statman, M., 2000. Socially responsible mutual funds. Financial Analysts Journal (May-June), 30-39. 